DOI: $10.31393 /$ reports-vnmedical-2021-25(2)-28

UDC: $612.215 .4: 572$

\title{
MODERN VIEWS ON ANTHROPOMETRIC VARIABILITY OF THE UPPER AIRWAY (LITERATURE REVIEW) \\ Kostiuchenko-Faifor O. S.
}

National Pirogov Memorial Medical University, Vinnytsya (Pyrogov street, 56, Vinnytsya, Ukraine, 21018)

Responsible for correspondence: e-mail: kostyuchenko.olha.91@gmail.com

Received: May, 17, 2021; Accepted: Jun, 11, 2021

Annotation. The versatility and complexity of the structure of the upper airway is the subject of research by researchers in various fields of medicine. In particular, the greatest attention is paid to infectious diseases, injuries and their consequences, congenital pathologies of the upper airway. However, to understand certain processes in the human body, in particular pathological, it is necessary to know which indicators of the upper airway should be considered normal and what can affect their value. The purpose of this work is to systematize information and acquaint with modern views on anthropometric variability of the upper airway. To achieve this goal, an analysis of literature sources not older than 10 years, included in the scientometric databases Scopus, Web of Science and Google Academy. A study of scientific papers has shown that the most effective and appropriate method of studying the indicators of the upper airway for further anthropometric analysis is a cephalometric study. The analysis of foreign literature showed the importance of the influence of such factors as sex, age, nationality and structural features of cranial and dental-maxillary parameters on the cephalometric parameters of the upper airway. In the analysis of the domestic literature, research performed in this direction was not found. Thus, conducting research to identify normative cephalometric indicators of the upper airway in the Ukrainian population, taking into account the experience of foreign scientists is a promising and relevant area of research for both theoretical and clinical medicine in Ukraine. Keywords: upper airway, comparative anatomy, somatic constitution, cephalometric parameters.

\section{Introduction}

The human respiratory tract is divided into upper airway and lower airway in accordance with generally accepted norms of anatomy. However, there is still no unanimous opinion among scientists about the boundary between them. The most common and acceptable statement is that the boundary between them passes through the laryngopharynx (part of the upper airway), the upper limit of which corresponds to the level of the hyoid bone [22]. That is, in general, the complex of the upper airway (UA) includes the nasal cavity, paranasal sinuses and pharynx. These structures participate in the performance of such key functions as respiration, speech, smell. In addition, the UA is an important barrier to protection against infectious diseases and has a cushioning function [29].

UA pathologies are represented by congenital malformations, infectious diseases, injuries and oncological lesions. Congenital malformations include choan atresia, congenital fibroelastic laryngeal membrane, and stenosis; soft tissue abscesses and laryngitis are the most common infectious lesions of the airways; post-traumatic stenosis, aspiration by foreign bodies, burns, typical traumatic lesions of the airway, which occur in clinical practice [16]. Thus, there is a need to get acquainted with modern scientific publications concerning the norm and pathology of UA.

The purpose of the study is to systematize information and acquaint with modern views on anthropometric variability of the upper airway.

\section{Materials and methods}

The analysis of scientometric databases Scopus, Web of Science and Google Academy for the period 2010-2021 is carried out.

\section{Results. Discussion}

In general, the study of UA parameters in various pathological conditions is a separate topic of modern research. Thus, scientists studied a sample of 52 people (including 26 healthy people in the control group) with bronchial asthma. Subjects were examined by computed tomography followed by evaluation of cephalometric parameters. Patients with bronchial asthma were found to have statistically lower overall UA and oropharyngeal narrowness ( $p=0.01$ and $p=0.007$, respectively) than controls [5].

Indicators of UA have the features at persons with obstructive sleep apnea at a syndrome craniosynostosis. Compared with the control sample, such individuals have higher indicators of the length of the UA, and the severity of retrusion of the middle part of the face $(p=0.016$ and $p=0.022$, respectively) and smaller indicators of the space of the posterior respiratory tract $(p=0.01)[6]$.

In individuals with combined obstructive sleep apnea and erectile dysfunction according to the results of binary step-by-step model analysis, the only reliable indicator of UA that can be used in the prognostic model is an increase in the length of the soft palate and tongue $(\mathrm{OR}=1.129,95 \%$ $\mathrm{Cl}=1.0005-1.268, \mathrm{p}=0.041$ ) [7].

In the case of Treacher Collins syndrome, even despite the presence of micrognathia and retrognathia in such patients, no statistically significant difference in UA compared to healthy individuals was found [26].

The length of UA can be used to predict the severity of obstructive sleep apnea. Statistical analysis of the data revealed that the length of $U A \geq 72 \mathrm{~mm}$ for men and $\geq 62 \mathrm{~mm}$ 
for women was associated with the presence of obstructive sleep apnea $(p=0.03)$ and strongly correlated with the severity of the disease in men and moderately in women $(r=0.72, p<0.01$ and $r=0.52, p<0.01$, respectively) [31].

W. G. Vos and co-authors also report on the prospects of using an anthropometric approach to address the issue of predicting the severity of obstructive sleep apnea [32].

A group of scientists led by L. Xu [33] in their study emphasize that when predicting this disease must also take into account the nationality of the subject. There were significant differences in the morphology of Icelanders and Chinese suffering from obstructive sleep apnea: Chinese nationals had lower values of almost all anthropometric parameters (both cranial, facial and UA) except the volume of the soft palate $(p \leq 0.001)$.

The detection of the above connections is quite expected and logically fits into the concept of clinical and comparative anthropology in general and corresponds to other studies performed in this area, in particular concerning dermatoglyphics [13] and dentistry [21].

It should be noted that a key element in determining the cephalometric parameters of UA is the use of non-invasive instrumental method of research - teleradiography. This radiographic method of research is a reference and indispensable in determining and evaluating both the location of cephalometric landmarks and the assessment of the volume and size of certain structures of the UA.

Recently, however, scientists and clinicians have questioned the possible effectiveness of computed tomography (CT). X. Feng et al. [9] for this purpose conducted a comparative study, the results of which showed that teleradiographic and CT methods have significantly the same accuracy in determining almost all indicators except airway volume (more accurate CT) and adenoid nasopharyngeal ratio (more accurate indicators in teleradiographic examination).

At the same time, M. G. Lenza et al. [18] argue that more accurate indicators can be obtained by CT examination. Thus, this issue still remains open to the scientific community.

The unambiguity of the opinions of scientists can be observed in the study of the impact of sex, age and other constitutional indicators on the parameters of UA - all the data indicate their obvious relationship. For example, a survey of 22 obese people and obstructive sleep apnea and 22 people with obstructive sleep apnea but normal weight found that the former had smaller oropharyngeal sizes $(p<0.05)$, larger tonsils, and retropharyngeal nodes $(p<0.05)$ [3].

In addition, data from another study show that individuals with this disease also have a lower sublingual bone location, longer soft palate length, and greater neck girth $(p<0.05)[11]$.

In the analysis of 390 lateral cephalograms of men and women of 13 age groups, a group of researchers found that such indicators as the width of the UA and the length of the upper lip increase with age (especially rapidly increases the lower width of the UA at the age of 6 to 18 years); moreover, the width of the airway was significantly greater in women [12].

Noteworthy are the studies of K. S. Guttal and K. N. Burde [14], which aimed to determine the normative indicators of UA in healthy individuals with the correct craniofacial parameters. Analysis of a sample of 60 people (30 men and 30 women) revealed manifestations of sexual dimorphism for almost all indicators except the width of the airway and the length of the soft palate. However, it should be noted that the authors did not mention whether the authors took into account the nationality of the respondents.

In the examination of obese persons, of the 12 cephalometric indicators of UA studied, a statistically significant difference was found only for the indicator of the distance from the plane of the mandible to the hyoid bone $(p=0.003)$ [17].

Age differences in the sizes of UA are revealed. In a study of two groups of people aged 7-11 years and 12-17 years, it was found that the ratio of $\mathrm{A} / \mathrm{N}$ was 0.45 and 0.44 for the age groups 7-11 and 12-17 years, respectively. The values of PNS-ad1 and PNS-ad2 were 24 and $18.7 \mathrm{~mm}$, respectively, for persons aged 7-11 years and 26.7 and $21.2 \mathrm{~mm}$ for persons aged $12-17$ years. The greatest correlation with age had the length of UA $(r=0,557, p<0,001)$ [23].

Japanese scientists have proposed a mathematical model for predicting the normal growth of UA based on the indicators of lateral teleradiograms. As a result, the authors of the study created two models - the equation of increase in the height of the UA depending on the nasopharyngeal to oropharyngeal airway volume and the nasopharyngeal airway to GoT-MLPW [30].

No less numerous are the works on the study of associations of ethnicity and indicators of UA. The group of authors established the features of UA indicators for children, residents of the South-East region of Asia, suffering from obstructive sleep apnea [1].

Indian scientists have identified features of the parameters of UA for the inhabitants of South India. The obtained data are proposed to be used to predict the severity of intubation of patients [4].

Analysis of a sample of 281 people (140 girls and 140 boys aged 6-18 years) revealed pronounced manifestations of sexual dimorphism in the indicators of UA - boys had higher and longer UA than girls [19].

The group of scientists analyzed the teleradiograms of 425 children of Chinese origin and 108 children of European origin aged 12 years. 9 indicators of UA and 14 craniofacial indicators were analyzed. No sexual dimorphism was found in the sample of European children, while in the Chinese sample it was found that boys have smaller depths of the pharyngeal and posterior pharyngeal spaces $(p=0.034$ and $p<0.001$, respectively) and greater 
indicators of the thickness of the soft palate $(p=0.008)$ compared with girls. The most significant differences between the Chinese and European samples were found for the position of the hyoid bone (boys only) [24].

The study of the inhabitants of Northern India revealed pronounced manifestations of sexual dimorphism for most indicators of UA, except for the depth of the oropharynx and the minimum depth of UA [27].

A separate category of scientists' work concerns the search for correlations between cranial and odontological indicators and UA indicators. Work in this direction is quite successful and productive [8].

The researchers compared craniofacial parameters in two groups of subjects - in healthy individuals and patients with obstruction of the UA. Patients with UA obstruction had retrognathism and hypoplasia of the mandible and a higher hard palate [2].

Iranian scientists conducted a study to assess the interdependence of UA indicators and the profile of the human face. The only craniofacial indicator that is statistically significantly associated with VDS is the angle of the mandibular plane $(p=0.028)$ [10].

I. Indriksone and G. Jakobsone [15] found associations between nasopharyngeal airway volume and SNA angle, sex, and between SNB angle and oropharyngeal airway volume $(r=0.144, p<0.05)$.

\section{References}

[1] Abdullah, B., Rajet, K. A. M., Abd Hamid, S. S., \& Mohammad, W. M. Z. W. (2011). A videoendoscopic evaluation of the upper airway in South East Asian adults with obstructive sleep apnea. Sleep and Breathing, 15(4), 747-754. https://doi.org/ 10.1007/s11325-010-0431-7

[2] Ardehali, M. M., Zarch, V. V., Joibari, M. E., \& Kouhi, A. (2016). Cephalometric assessment of upper airway effects on craniofacial morphology. Journal of Craniofacial Surgery, 27(2), 361-364. https://doi.org/10.1097/ SCS.0000000000002388

[3] Arens, R., Sin, S., Nandalike, K., Rieder, J., Khan, U. I., Freeman, K., ... \& Shifteh, K. (2011). Upper airway structure and body fat composition in obese children with obstructive sleep apnea syndrome. American journal of respiratory and critical care medicine, 183(6), 782-787. https://doi.org/10.1164/ rccm.201008-12490C

[4] Balakrishnan, K. P., \& Chockalingam, P. A. (2017). Ethnicity and upper airway measurements: A study in South Indian population. Indian journal of anaesthesia, 61(8), 622-628. https://doi.org/10.4103/ija.IJA $247 \quad 17$

[5] Bandeira, A. M., Oltramari-Navarro, P. V. P., de Lima Navarro, R., de Castro Ferreira Conti, A. C., de Almeida, M. R. \& Fernandes, K. B. P. (2014). Three-dimensional upper-airway assessment in patients with bronchial asthma. The Angle Orthodontist, 84(2), 254-259. https://doi.org/10.2319/030113-176

[6] Dentino, K., Ganjawalla, K., Inverso, G., Mulliken, J. B., \& Padwa, B. L. (2015). Upper airway length is predictive of obstructive sleep apnea in syndromic craniosynostosis. Journal of oral and maxillofacial surgery, 73(12), S20-S25. https://doi.org/ 10.1016/j.joms.2015.04.017

[7] Drakatos, P., Karkoulias, K., Giannitsas, K., Kalogeropoulou, C., Papapanagiotou, N., Lykouras, D., ... \& Spiropoulos, K. (2016). Computed tomography cephalometric and upper airway measurements in patients with OSA and erectile dysfunction.
Another study found a statistically significant negative correlation between the width of the upper pharynx and the angle ANB, the width of the lower pharynx and the distance from the upper and lower lips to the $E$ line [20].

When dividing persons by facial types, the authors of the publication found a statistically significant difference in the median posterior-palatal space between persons with brachyfacial and dolichofacial types of face [28].

\section{Conclusions and prospects for further development}

1. Given the widely covered in the scientific literature such aspects as: the key role of cephalometric analysis in the assessment of upper airway; the presence of interdependencies between cephalometric indicators and indicators of the dental-maxillary system; variability of the upper airway depending on sex, age and ethnicity; wide prevalence of pathologies that in one way or another depend on the structure of the upper airway - there is a need for experimental research to identify normative indicators of the upper respiratory tract for Ukrainians, taking into account sex, age and occlusion.

The results of such a study would be not only the basis for understanding the norm but the foundation for further research to identify and assess pathology, and would have practical application in various fields of medicine.

Sleep and Breathing, 20(2), 769-776. https://doi.org/10.1007/ s11325-015-1297-5

[8] Farina, R., Gonzalez, A., Toledo, X., Villanueva, R., Martinez, B., \& Perez, H. (2019). Relationship between nostril, nasal valve and minimal cross-sectional area in functional upper airway. Journal of Craniofacial Surgery, 30(7), 2202-2206. https:// doi.org/10.1097/SCS.0000000000005791

[9] Feng, X., Li, G., Qu, Z., Liu, L., Nasstrom, K., \& Shi, X. Q. (2015). Comparative analysis of upper airway volume with lateral cephalograms and cone-beam computed tomography. American Journal of Orthodontics and Dentofacial Orthopedics, 147(2), 197-204. https://doi.org/10.1016/ j.ajodo.2014.10.025

[10] Gholinia, F., Tavanayan, F., Afsari Ardchi, E., \& Nemati, S. (2019). Evaluating the relationship between dimensions of the upper airway and facial profile according to initial lateral cephalometric radiography in orthodontic patients in the north of Iran. Orthodontic Waves, 78(3), 126-134. https://doi.org/ 10.1016/j.odw.2019.08.001

[11] Ghosh, P., Varma, N. S., Ajith, V. V., \& Suresh, A. (2021). Upper Airway and its Association with Neck Circumference and Hyoid Position in OSA Subjects-A Cephalometric Study. Int $J$ Cur Res Rev, 13(06), 167-171. http://dx.doi.org/10.31782/ IJCRR.2021.13610

[12] Goncalves, R. D. C., Raveli, D. B., \& Pinto, A. D. S. (2011). Effects of age and gender on upper airway, lower airway and upper lip growth. Brazilian oral research, 25, 241-247. https://doi.org/10.1590/S1806-83242011000300009

[13] Gunas, V. I., Mishalov, V. D., Serebrennikova, O. A., Klimas, L. A., \& Shayuk, A. V. (2018). Palmar dermatoglyphics of modern Ukrainians: regional trends. Biomedical and biosocial anthropology, (31), 11-17. https://doi.org/10.31393/bba312018-02

[14] Guttal, K. S., \& Burde, K. N. (2013). Cephalometric evaluation 
of upper airway in healthy adult population: a preliminary study. Journal of Oral and Maxillofacial Radiology, 1(2), 55-60. https:/ /doi.org/10.4103/2321-3841.120115

[15] Indriksone, I., \& Jakobsone, G. (2015). The influence of craniofacial morphology on the upper airway dimensions. The Angle Orthodontist, 85(5), 874-880. https://doi.org/10.2319/ 061014-418.1

[16] Jardine, D., Bhutta, O. J., \& Inglis, A. (2011). Specific diseases of the respiratory system: upper airway. Pediatric critical care, 561-574. https://doi.org/10.1016/B978-0-323-073073.10044-8

[17] Kim, T. H., Chun, B. S., Lee, H. W., \& Kim, J. S. (2010). Differences of upper airway morphology according to obesity: study with Cephalometry and dynamic MD-CT. Clinical and experimental otorhinolaryngology, 3(3), 147-152. https:// doi.org/10.3342/ceo.2010.3.3.147

[18] Lenza, M. G., Lenza, M. D. O., Dalstra, M., Melsen, B., \& Cattaneo, P. M. (2010). An analysis of different approaches to the assessment of upper airway morphology: a CBCT study. Orthodontics \& craniofacial research, 13(2), 96-105. https:/ /doi.org/10.1111/j.1601-6343.2010.01482.x

[19] Li, H., Lu, X., Shi, J., \& Shi, H. (2011). Measurements of normal upper airway assessed by 3-dimensional computed tomography in Chinese children and adolescents. International journal of pediatric otorhinolaryngology, 75(10), 1240-1246. https://doi.org/10.1016/j.ijporl.2011.06.022

[20] Lopatiene, K., Sidlauskas, A., Vasiliauskas, A., Çeçyte, L., Svalkauskiene, V., \& Sidlauskas, M. (2016). Relationship between malocclusion, soft tissue profile, and pharyngeal airways: A cephalometric study. Medicina, 52(5), 307-314. https://doi.org/10.1016/j.medici.2016.09.005

[21] Marchenko, A. V., Shinkaruk-Dykovytska, M. M., Pozur, T. P., Gunas, V. I., \& Orlovskiy, V. O. (2020). Models of individual linear dimensions necessary for the construction of the correct form of dental arches in young men with a wide face, depending on the features of odontometric and cephalometric indicators. Wiadomosci lekarskie (Warsaw, Poland: 1960), 73(6), 11031107. https://doi.org/10.36740/WLek202006104

[22] Marieb, E. N., \& Brito, S. (2017). Anatomy and Physiology Coloring Workbook. Pearson Australia Pty Limited.

[23] Masoud, A. I., \& Alwadei, F. H. (2021). Two-dimensional upper airway normative values in children aged 7 to 17 years. CRANIO®, $\quad 1-8 . \quad$ https://doi.org/10.1080/ 08869634.2021 .1943137

\section{СУЧАСН ПОГЛЯДИ ЩОДО АНТРОПОМЕТРИЧНОЇ МІНЛИВОСТІ ВЕРХНІХ ДИХАЛЬНИХ ШЛЯХІВ (ОГЛЯД ЛІТЕРАТУРИ) Костюченко-Файфор О. С.}

Анотація. Багатофункціональність та складність будови верхніх дихальних шляхів є предметом роботи дослідників різних направленостей медицини. Зокрема, найбільша увага приділяється інфекційним захворюванням, травмам та їх наслідкам, вродженим патологіям верхніх дихальних шляхів. Проте для розуміння тих чи інших процесів в організмі людини, зокрема патологічних, необхідно знати, які показники верхніх дихальних иляхів слід вважати нормою і що може впливати на їх значення. Мета даної роботи - систематизація інформації та ознайомлення з сучасними поглядами щодо антропометричної мінливості верхніх дихальних шляхів. Для досягнення цієї мети проведено аналіз літературних джерел давністю не більше 10 років, що входять до наукометричних баз Scopus, Web of Science ma Google Academy. Проведене дослідження наукових праць показало, що найбільш ефективним і доцільним методом вивчення показників верхніх дихальних шляхів 3 метою подальшого антропометричного аналізу є проведення цесралометричного дослідження. Аналіз іноземної літератури засвідчив значущість впливу таких фракторів як стать, вік, національність та особливості будови краніальних та зубощелепних показників, на иесралометричні показники верхніх дихальних иляхів. При аналізі вітчизняної літератури досліджень виконаних у даному напрямку не було виявлено. Таким чином, проведення дослідження з метою виявлення нормативних иефалометричних показників верхніх дихальних шляхів в українській популяції, з врахуванням досвіду зарубіжних науковців є перспективним і актуальним напрямком дослідження як для теоретичної так і для клінічної медицини в Україні. Ключові слова: верхні дихальні шляхи, порівняльна анатомія, соматична конституція, цефралометричні параметри.
"Вісник Вінницького національного медичного університету", 2021, T. 25, №2 